\title{
Article \\ Residual Impact Performance of ECC Subjected to Sub-High Temperatures
}

\author{
Raad A. Al-Ameri ${ }^{1}$, Sallal Rashid Abid ${ }^{2}, * \mathbb{E}$, Gunasekaran Murali ${ }^{3}$, Sajjad H. Ali ${ }^{2}$, Mustafa Özakça ${ }^{1} \mathbb{C}$ \\ and Nikolay Ivanovich Vatin ${ }^{4}[$
}

1 Department of Civil Engineering, Faculty of Engineering, Gaziantep University, Gaziantep 27310, Turkey; raada.alameri@gmail.com (R.A.A.-A.); ozakca@gantep.edu.tr (M.Ö.)

2 Department of Civil Engineering, College of Engineering, Wasit University, Kut 52003, Iraq; sajhali.wasit@gmail.com

3 School of Civil Engineering, SASTRA Deemed University, Thanjavur 613401, India; murali_22984@yahoo.com

4 Peter the Great St. Petersburg Polytechnic University, 195251 St. Petersburg, Russia; vatin@mail.ru

* Correspondence: sallal@uowasit.edu.iq

check for updates

Citation: Al-Ameri, R.A.; Abid, S.R.; Murali, G.; Ali, S.H.; Özakça, M.;

Vatin, N.I. Residual Impact

Performance of ECC Subjected to

Sub-High Temperatures. Materials

2022, 15, 454. https://doi.org/

$10.3390 / \mathrm{ma} 15020454$

Academic Editor: Wang Qiang

Received: 23 November 2021

Accepted: 27 December 2021

Published: 7 January 2022

Publisher's Note: MDPI stays neutral with regard to jurisdictional claims in published maps and institutional affiliations.

Copyright: (C) 2022 by the authors. Licensee MDPI, Basel, Switzerland. This article is an open access article distributed under the terms and conditions of the Creative Commons Attribution (CC BY) license (https:// creativecommons.org/licenses/by/ $4.0 /)$.

\begin{abstract}
Despite the fact that the mechanical properties of Engineered Cementitious Composites (ECC) after high-temperature exposure are well investigated in the literature, the repeated impact response of ECC is not yet explored. Aiming to evaluate the residual impact response of ECC subjected to sub-high temperatures under repeated drop weight blows, the ACI 544-2R repeated impact test was utilized in this study. Disk impact specimens (150 mm diameter and $64 \mathrm{~mm}$ thickness) were prepared from the M45 ECC mixture but using polypropylene fibers, while similar $100 \mathrm{~mm}$ cube specimens and $100 \times 100 \times 400 \mathrm{~mm}$ prism specimens were used to evaluate the compressive and flexural strengths. The specimens were all cast, cured, heated, cooled, and tested under the same conditions and at the same age. The specimens were subjected to three temperatures of 100, 200 and $300{ }^{\circ} \mathrm{C}$, while a group of specimens was tested without heating as a reference group. The test results showed that heating to 100 and $200{ }^{\circ} \mathrm{C}$ did not affect the impact resistance noticeably, where the retained cracking and failure impact numbers and ductility were higher or slightly lower than those of unheated specimens. On the other hand, exposure to $300{ }^{\circ} \mathrm{C}$ led to a serious deterioration in the impact resistance and ductility. The retained failure impact numbers after exposure to 100, 200, and $300{ }^{\circ} \mathrm{C}$ were 313,257 , and 45 , respectively, while that of the reference specimens was 259 . The results also revealed that the impact resistance at this range of temperature showed a degree of dependency on the compressive strength behavior with temperature.
\end{abstract}

Keywords: ECC; repeated impact; high temperatures; ACI 544-2R; drop-weight; impact ductility

\section{Introduction}

The conventional normal strength concrete has been a perfect building solution since the spread of Portland cement production. However, with the developments in building materials technology, new concrete types that possess better characteristics were introduced. The need for cementitious materials that can absorb high plastic energy before failure was the reason to design and introduce what is known as Engineered Cementitious Composites (ECC). ECC is a kind of flowable concrete that has perfect fresh properties and superior plastic deformation resistance. This material was first introduced by Victor Li [1,2], who worked on the design of ECC that can sustain high deformations by virtue of multi-cracking behavior $[3,4]$. The material includes a much higher content of cementitious materials than conventional concrete that has a similar compressive strength, where in addition to cement, other cementitious materials such as fly ash and silica fume are used with significant contents. For instance, the basic M45 ECC mixture includes $570 \mathrm{~kg} / \mathrm{m}^{3}$ of cement, while the content of fly ash is $120 \%$ of cement content [5]. The presence of such contents can help reach the required fresh workability and the crack resisting characteristics. The use of 
very fine silica sand instead of the fine and coarse aggregates is also another reason for the material's behavior, while the existence of synthetic fibers can assure the active resistance to crack opening and propagation, which shifts the behavior to the multi-cracking mode. Numerous studies were conducted during the last two decades to study the properties of ECC under the different kinds of loads, to explore the effect of different types of materials and fibers on the mixture characteristics, and to evaluate the material behavior under extreme conditions [6-12].

Impacts from falling masses on beams and slabs or due to the collision of moving cars on columns or walls are types of accidental non-design loads. Such loads can cause serious localized damage that may influence the member's integrity or affect a part of the structure. The effect becomes more serious if these impacts are repeated several times. Examples of repeated impacts are the columns of parking garages that are subjected to daily high traffic with the possibility of repeated impacts by moving vehicles [13]. The tire impact of the landing aircraft on the airport runways is also another example of repeated impacts [14]. The water velocity reducing elements in hydraulic structures such as chute blocks in stilling basins are continuously subjected to repeated impacts from the high-velocity water and the carried debris [15]. Therefore, the performance of concrete materials and structural members under the influence of impact loads was the focus of research for decades. Several testing procedures are available to evaluate the different impacting loads depending on the velocity of the impactor and its direction. For instance, high strain rate tests, such as the projectile testing method, evaluate the performance of a structural member targeted by any kind of projectiles in war cases, conflict areas, or terrorist attacks $[16,17]$. On the other hand, tests such as drop-weight impact and Charpy pendulum test are more frequently used to assess the impact resistance of materials. However, these tests do not consider the effect of a repeat of impacts, while the ACI 544-2R [18] introduces a very simplified procedure to evaluate the material response to repeated falling impacts qualitatively. The test does not require measurements of load, deformation, or vibration, where only the count of impact blows is considered in the procedure. This test was recently facilitated by several researchers for the purpose of comparing the influence of adopting different materials and fiber types on the impact performance of concrete. The impact performance of concrete with polypropylene fibers [19-22], micro-steel fibers [23], steel fibers [24-26], carbon fibers [27,28], natural fibers [29], and hybrid fibers [30-33] was investigated recently. Significant research works were recently conducted to study the influence of fiber type, fiber dosage, fiber distribution, and intermediate fiber meshes on improving the impact resistance of preplaced aggregate concrete with single, double, and triple layers [34-39]. On the other hand, the research on the repeated impact behavior of ECC is very limited in the literature. The influence of fly ash, silica fume, slag, and metakaolin in different combined dosages on the repeated impact performance of ECC was investigated by Ismail et al. [40], where increasing the dosages of fly ash and metakaolin was found to give the highest impact numbers.

Despite the technological advances in fire control systems, trusted fire records reported thousands of accidental structural fires every single year all over the world [41]. Owing to the non-stop advances in construction materials technology, research on this topic is always required to help engineers make their decisions about the probable post-fire occupation of fire-exposed structures [42,43]. Extensive research works are available on the effect of high temperatures on the residual mechanical properties of concrete after fire exposure and post-fire structural evaluation of structures [44,45]. The changes of the concrete microstructure after reaching the different levels of temperature control the percentage residual strength. The pore water vaporization beyond $100{ }^{\circ} \mathrm{C}$ was reported to mostly have a positive effect on the compressive strength [46-49], while the serious strength reduction starts beyond 300 to $400{ }^{\circ} \mathrm{C}$, where the chemical decomposition of calcium silicate hydroxide strongly deteriorates the material's microstructure [50-54]. The influence of fire exposure on the compressive strength, tensile strength, flexural strength, shear strength, and elastic modulus of different concrete types was extensively studied 
in the literature [55-59]. Similarly, some previous studies were conducted to investigate the post-fire impact performance of concrete. However, most of them did not consider the repeated impact scenario, while very few researches were conducted using the repeated impact procedure. Mehdipour et al. [60] carried out mechanical and repeated impact tests on concrete specimens subjected to temperatures up to $600{ }^{\circ} \mathrm{C}$. They investigated the effect of the partial replacements of cement by metakaolin and coarse aggregate by crumb rubber. Their results revealed a destructive effect of high temperatures on the retained impact numbers, where specimens exposed to $600{ }^{\circ} \mathrm{C}$ cracked after one impact. Al-Ameri et al. [61] studied the ACI 544-2R repeated impact performance of normal weight-normal strength concrete after exposure to high temperatures. The results showed that the effect of $100{ }^{\circ} \mathrm{C}$ on the retained impact numbers was minimal, while the residual impact strength after heating to $600{ }^{\circ} \mathrm{C}$ was less than $4 \%$. On the other hand, some researches on the residual mechanical properties of ECC after exposure to fire temperatures was also conducted by previous researchers [62-68].

From the above-introduced literature survey, it is obvious that very limited literature is currently available on the repeated drop-weight impact performance of ECC. Similarly, studies on the residual repeated impact strength of all concrete types after high temperatures are rare. However, to the best of the authors' knowledge, no previous research was conducted to evaluate the residual repeated impact strength of ECC exposed to elevated temperatures. Therefore, the experimental study presented in this research was directed to highlight this uncovered issue and fill this gap of knowledge. For this purpose, ECC disk specimens were exposed to sub-high temperatures, and their residual repeated impact strength was investigated using the procedure of ACI 544-2R [18].

\section{Experiential Study}

\subsection{Materials and Mixtures}

The M45 ECC basic mixture [5] was adopted with the same original material quantities but using polypropylene (PP) fibers instead of polyvinyl alcohol (PVA) fibers. In the cubic meter of this mixture, $570 \mathrm{~kg}$ of Portland cement was used in combination with $684 \mathrm{~kg}$ of fly ash, which means that the cement/fly ash ratio was 1.2. The 2 materials composed the high content binder of this mixture, while the only filler used was fine graded silica sand, respectively. The filler/cement ratio was 0.8 , where $455 \mathrm{~kg}$ of silica sand was utilized in the mixture with $330 \mathrm{~kg}$ of mixing water and $4.9 \mathrm{~kg}$ of super-plasticizer. The PP fibers were used at a volumetric content of $2 \%$.

Type I (class 42.5R) ordinary Portland cement was adopted with the chemical characteristics and physical properties shown in Table 1, which also lists the main characteristics of the fly ash. On the other hand, graded silica sand $(0.08$ to $0.25 \mathrm{~mm})$ from Sika ${ }^{\circledR}$ with a $1500 \mathrm{~kg} / \mathrm{m}^{3}$ bulk density was used as the filler of the mixture. To assure the required fresh workability of ECC, ViscoCrete 5930-L produced by Sika ${ }^{\circledR}$ was mixed with the mixture's water. The length and diameter of the used PP fiber were 12 and $0.032 \mathrm{~mm}$, while its density was $910 \mathrm{~kg} / \mathrm{m}^{3}$. On the other hand, the tensile strength and elastic modulus of the used PP fiber were 400 and $4000 \mathrm{MPa}$, respectively.

Table 1. Characteristics of cement and fly ash.

\begin{tabular}{ccc}
\hline Oxide (\%) & Cement (\%) & Fly Ash (\%) \\
\hline $\mathrm{SiO}_{2}$ & 20.08 & 56.0 \\
$\mathrm{Fe}_{2} \mathrm{O}_{3}$ & 3.6 & 24.81 \\
$\mathrm{Al}_{2} \mathrm{O}_{3}$ & 4.62 & 5.3 \\
$\mathrm{CaO}$ & 61.61 & 4.8 \\
$\mathrm{MgO}$ & 2.12 & 1.48 \\
$\mathrm{SO}_{3}$ & 2.71 & 0.36 \\
\hline Loss on ignition $(\%)$ & 1.38 & 5.78 \\
Specific surface $\left(\mathrm{m}^{2} / \mathrm{kg}\right)$ & 368 & - \\
Specific gravity & 3.15 & 2.20 \\
Fineness (\% retain in $45 \mu \mathrm{m})$ & - & 28.99 \\
\hline
\end{tabular}




\subsection{Tests and Procedures}

Cube specimens with a side length of $100 \mathrm{~mm}$ were used to conduct the compressive strength test, while prism specimens with $100 \mathrm{~mm}$ square cross-section, $300 \mathrm{~mm}$ span, and $400 \mathrm{~mm}$ length was used to conduct the four-point flexural test to obtain the modulus of rupture (MOR). On the other hand, disk specimens were used per the recommendations of ACI 544-2R [18] to carry out the repeated impact tests. The specimens were $150 \mathrm{~mm}$ in diameter and $64 \mathrm{~mm}$ in depth. For each temperature level, 6 cubes, 6 prisms, and 6 disks were cast and cured in water containers for 28 days.

The impact specimens were tested under a falling weight of $4.54 \mathrm{~kg}$ and a falling depth of $457 \mathrm{~mm}$ as recommended by ACI 544-2R. The recommendations require that a steel ball of approximately $64 \mathrm{~mm}$ is placed on the top of the disk specimen and transfer the impacts from the falling weight to the specimen. The steel ball and the specimens should be held in their positions during the test using a special steel frame and lugs to prevent the rebound of the falling weight. As shown in Figure 1a, all these requirements were followed as recommended, where the impact tests were conducted using the specially made automatic falling mass testing machine shown in Figure $1 \mathrm{~b}$. The ACI 544-2R procedure recommends continuing to impact the specimens using the free-falling weight until the cracking of the top surface, where the number of impacts till this point is recorded as the cracking impact number. Then, the impact is resumed until the failure of the specimens by crack opening and fracture, at which the number of impacts is recorded as the failure impact number. To better observe the cracking and failure of the impact specimens, it is shown in Figure $1 b$ that a high accuracy camera was used to observe the surface condition of the tested specimen during the test. This test is known for its high variability, which implies the use of a larger number of specimens to control the variation of the results. Therefore, 6 impact disk specimens were used at each temperature level. It should be noticed that this test was defined as a qualitative test and was not intended to give exact numbers about the impact strength of concrete.

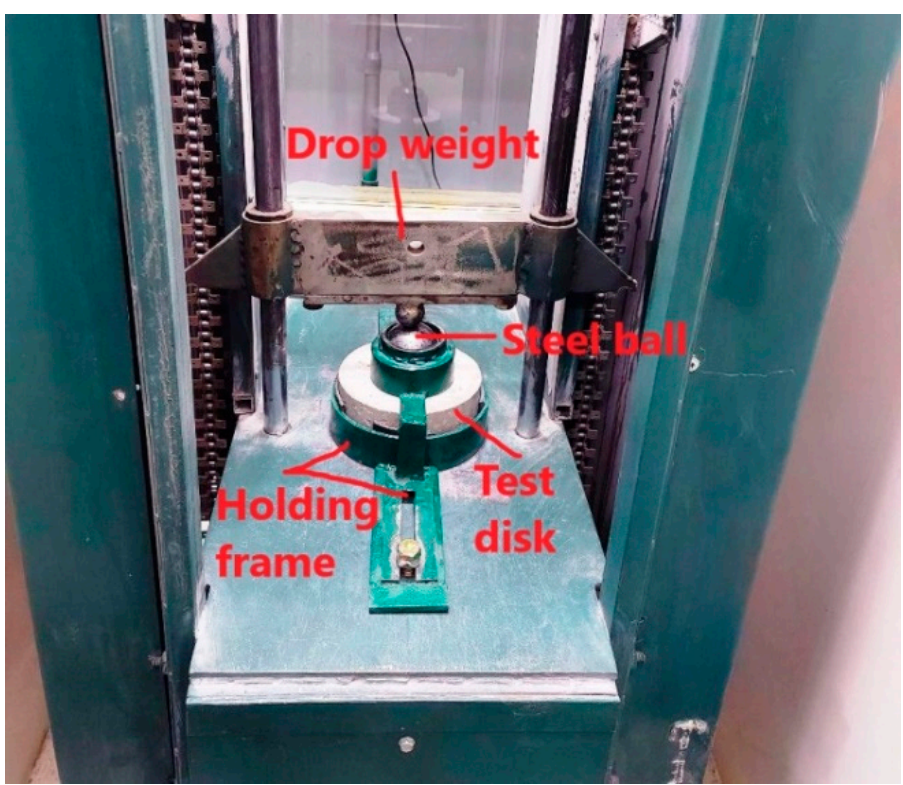

(a)

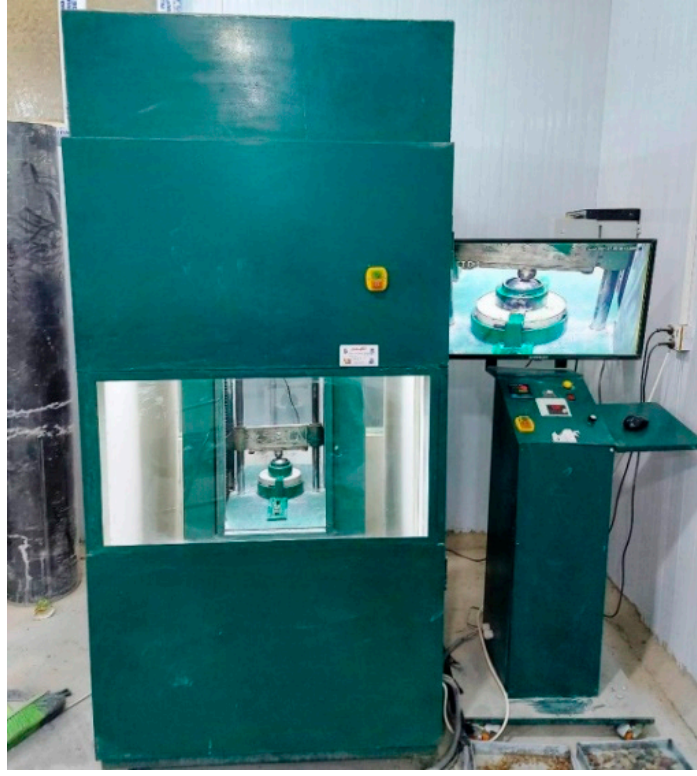

(b)

Figure 1. The impact testing (a) disk specimen's holding apparatus (b) testing machine.

\subsection{Furnace Heating}

A day before testing, the specimens were dried for $24 \mathrm{~h}$ using an electric oven at a temperature of $105^{\circ} \mathrm{C}$ to prevent the unfavorable explosive failure inside the furnace. The heating of the specimens to the desired levels of temperature was conducted using the 
electrical furnace shown in Figure 2. In addition to the room temperature, the specimens were subjected to three levels of sub-high temperatures, which were 100,200 , and $300{ }^{\circ} \mathrm{C}$. The heating rate of the furnace was kept approximately constant at $4{ }^{\circ} \mathrm{C} / \mathrm{min}$. As the desired temperature was reached, the furnace temperature was fixed for 60 min to thermally saturate the specimens at this temperature. Then, the furnace door was opened, and the specimens were naturally air-cooled until testing time. The regimes of heating and cooling of the 3 temperature levels are illustrated in Figure 3.

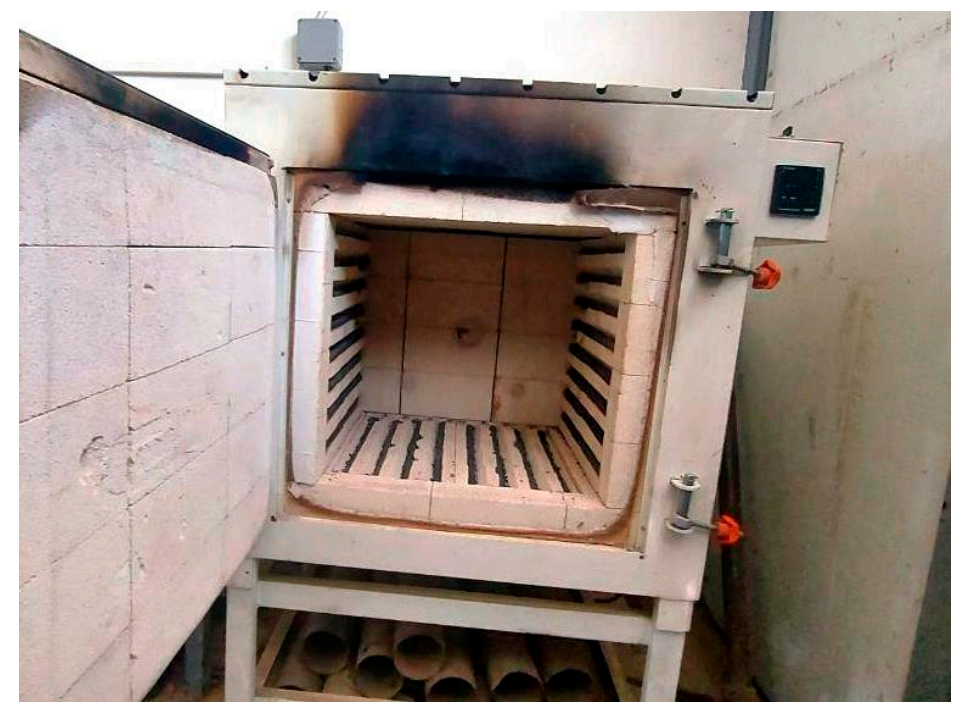

Figure 2. The interiors of the electric furnace.

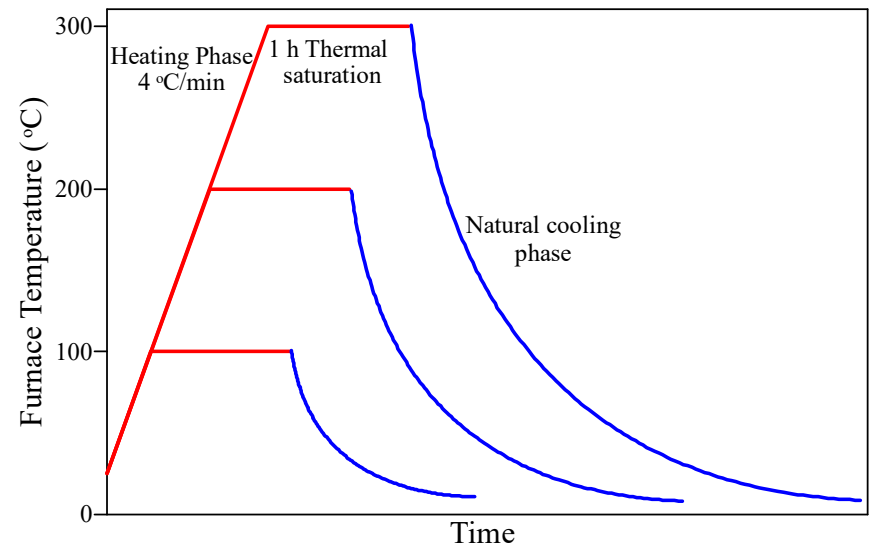

Figure 3. Furnace temperature-time relationships of the desired temperature levels.

\section{Compressive Strength Results}

As preceded, compressive strength cubes were cast, cured, heated, and tested at the same conditions as their corresponding impact test specimens. Figure 4 illustrates the influence of heating to the adopted three temperature levels on the compressive strength of the ECC specimens. Previous studies showed that the concrete compressive strength of ECC [69-71] increased in some cases after exposure to temperatures in the range of 100 to $300{ }^{\circ} \mathrm{C}$, or exhibited a partial recovery after exposure to $300^{\circ} \mathrm{C}$. Such behavior did not occur in this study, where the compressive strength of ECC exhibited a continuous decrease as temperature increased. However, the strength reduction after exposure to $100{ }^{\circ} \mathrm{C}$ was limited to approximately $4 \%$, as shown in Figure 4 , where the compressive strength decreased from 57.5 to $55.0 \mathrm{MPa}$. Another notice is that the strength reduction at $200{ }^{\circ} \mathrm{C}$ was comparable to that at $300{ }^{\circ} \mathrm{C}$, where the strength reduced to 44.8 and $44.4 \mathrm{MPa}$, respectively, exhibiting respective percentage decreases of 22 and $24.4 \%$. A 
similar continuous reduction of compressive strength of ECC with temperature was also reported by previous studies [62,63].

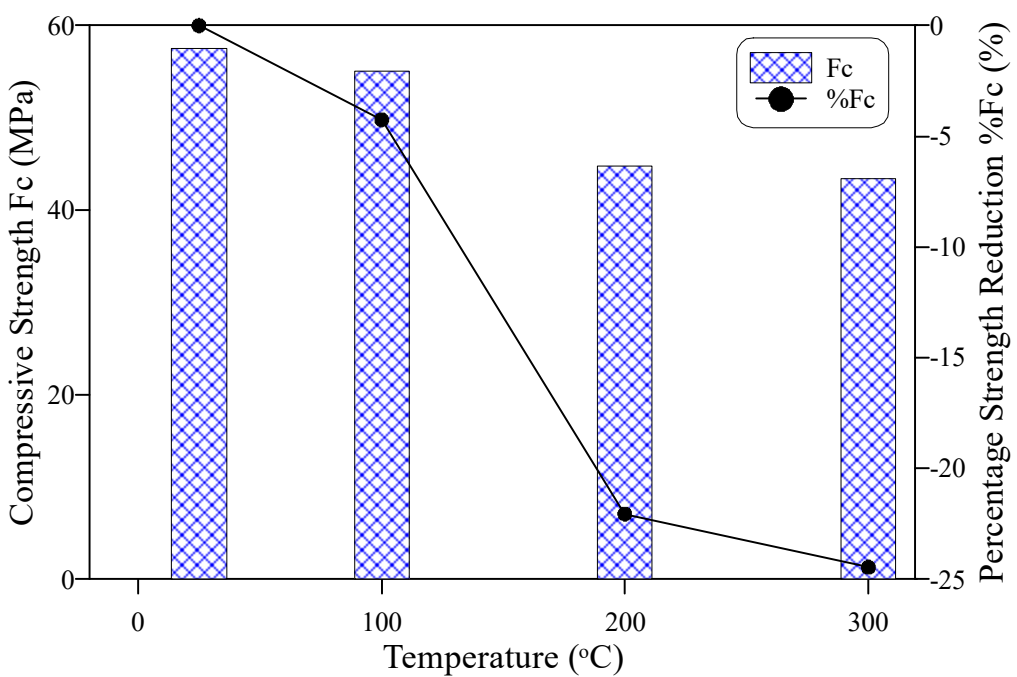

Figure 4. Compressive strength-temperature behavior.

\section{Flexural Strength Results}

The flexural strength was tested using the four-point bending setup to determine the modulus of rupture (MOR). The unheated ECC specimens exhibited the multi-cracking ductile behavior as shown in Figure 5, where all specimens showed more than five cracks that extended from the bottom surface of the beam specimen vertically towards the top-loading points as the load was increased. Finally, one of these cracks was opened wider, leading to the failure of the specimen. This cracking behavior assures the ductile performance of the adopted PP-based ECC. A similar cracking and failure performance was also recorded for the specimens exposed to $100^{\circ} \mathrm{C}$ as depicted in Figure 6b. However, the number of cracks was lesser than those in the unheated specimens. After exposure to $200{ }^{\circ} \mathrm{C}$, the specimens exhibited a brittle failure with only one crack that widened quickly under the loading increase (Figure 6c), while the specimens exposed to $300{ }^{\circ} \mathrm{C}$ exhibited a clear sudden brittle failure similar to that of normal concrete as shown in Figure $6 \mathrm{~d}$. Another notice is that the visual examination after failure revealed that the PP fibers were clearly bridging the two sides of the cracks of the unheated specimens and those exposed to $100{ }^{\circ} \mathrm{C}$, which explains their ductile behavior. On the other hand, such bridging activity was not observed for specimens exposed to higher temperatures due to the melting of the PP fibers at slightly below $200{ }^{\circ} \mathrm{C}$, which in turn explains the brittle failure of these specimens.

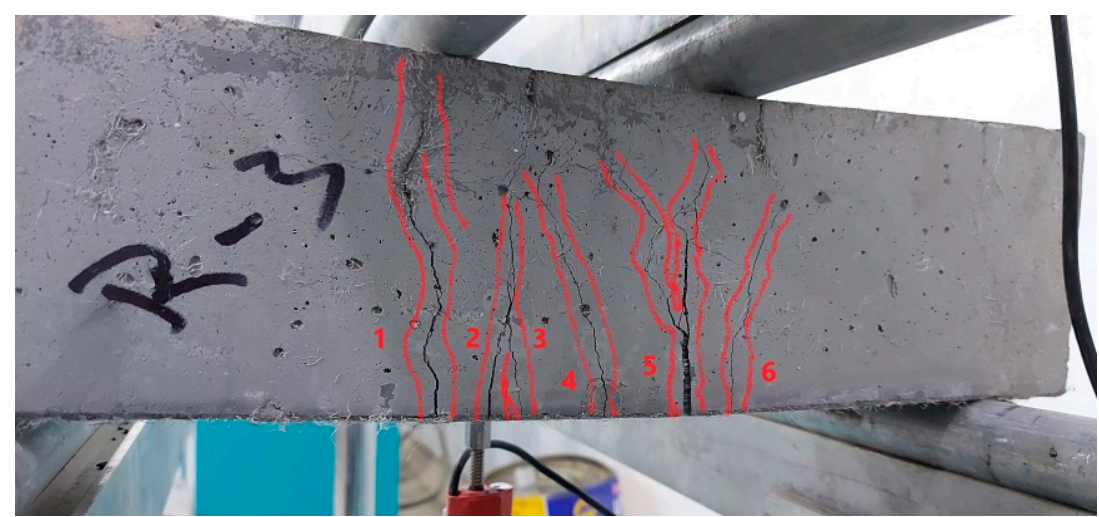

Figure 5. Multi-cracking failure of tested prisms. 


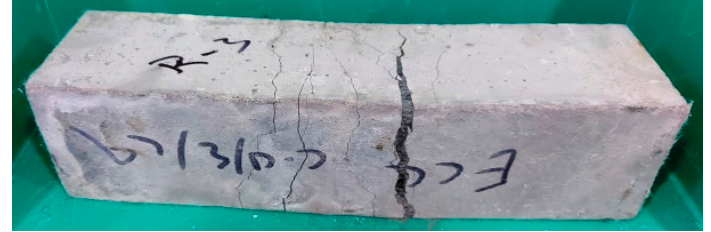

(a)

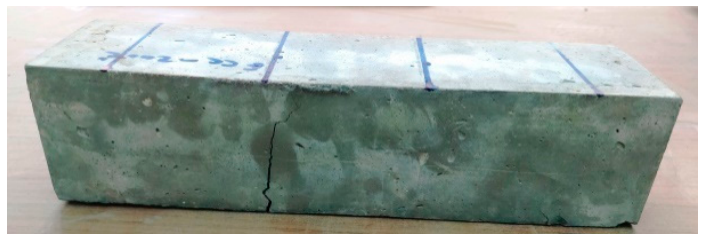

(c)

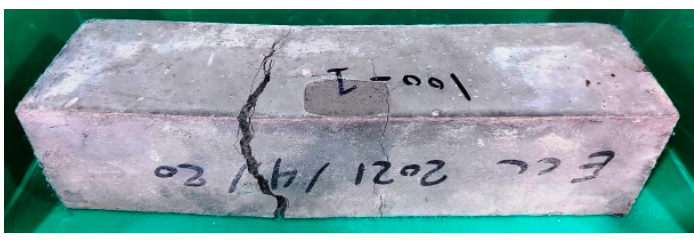

(b)

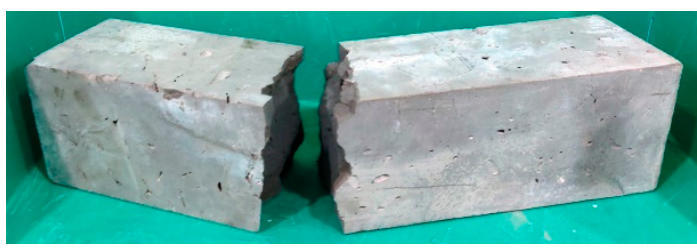

(d)

Figure 6. Failure of tested prisms exposed to different temperatures (a) Reference $\mathrm{R},(\mathbf{b}) 100{ }^{\circ} \mathrm{C}$, (c) $200{ }^{\circ} \mathrm{C}$, (d) $300{ }^{\circ} \mathrm{C}$.

Figure 7 shows the behavior of MOR with temperature increase. Similarly, the figure shows the percentage difference in MOR compared to the reference unheated MOR record. It can be seen in the figure that the MOR of the tested PP-ECC was not significantly affected by heating to temperatures up to $300{ }^{\circ} \mathrm{C}$. The recorded MOR of the reference unheated specimens was $6.94 \mathrm{MPa}$, while after exposure to $100{ }^{\circ} \mathrm{C}$, this value increased to $7.78 \mathrm{MPa}$, recording a percentage increase of $12.2 \%$ compared to the reference record. However, after exposure to 200 and $300{ }^{\circ} \mathrm{C}$, MOR reduced by 17 and $18.8 \%$, respectively, as clearly depicted in Figure 7. Thus, the MOR was kept within an approximately $\pm 20 \%$ difference with the unheated specimens. The increase in strength at $100{ }^{\circ} \mathrm{C}$ can be attributed to the densification of the material due to the vaporization of free pore water, while the melting of fibers after $200{ }^{\circ} \mathrm{C}$ left open micro-tubes inside the matrix that reduced its stiffness and weakened its structure $[63,72]$. Consequently, the strength was less than that before heating. The obtained trend of results in this study agrees with records reported by previous researchers [64]. However, the percentages of increase after $100{ }^{\circ} \mathrm{C}$ exposure and decrease after exposure to $200{ }^{\circ} \mathrm{C}$ and higher were different owing to the different mixtures, fiber types, heating regimes, and other reasons. For instance, Yu et al. [68] reported a percentage decrease of approximately $50 \%$ for ECC reinforced with PVA fibers after exposure to $200{ }^{\circ} \mathrm{C}$, while the percentage decrease at the same temperature was only $25 \%$ for specimens reinforced with both PVA and steel fibers. On the other hand, Wang et al. [71] reported a partial recovery at $100{ }^{\circ} \mathrm{C}$ after an initial decrease at $50^{\circ} \mathrm{C}$, followed by a significant decrease after exposure to temperatures of $200{ }^{\circ} \mathrm{C}$ and higher. To better visualize the effect of temperature on MOR taking into consideration its relation with the compressive strength, MOR was normalized by the square root of the corresponding compressive strength record at each temperature as depicted in Figure 8. As shown in the figure, the trend of the normalized MOR with temperature is quite similar to that of MOR. However, the percentage decrease values were affected by those of the compressive strength and reduced to approximately $6 \%$ after exposure to 200 and $300{ }^{\circ} \mathrm{C}$. This means that compressive strength could partially affect the behavior of flexural strength after exposure to temperatures up to $300^{\circ} \mathrm{C}$. 


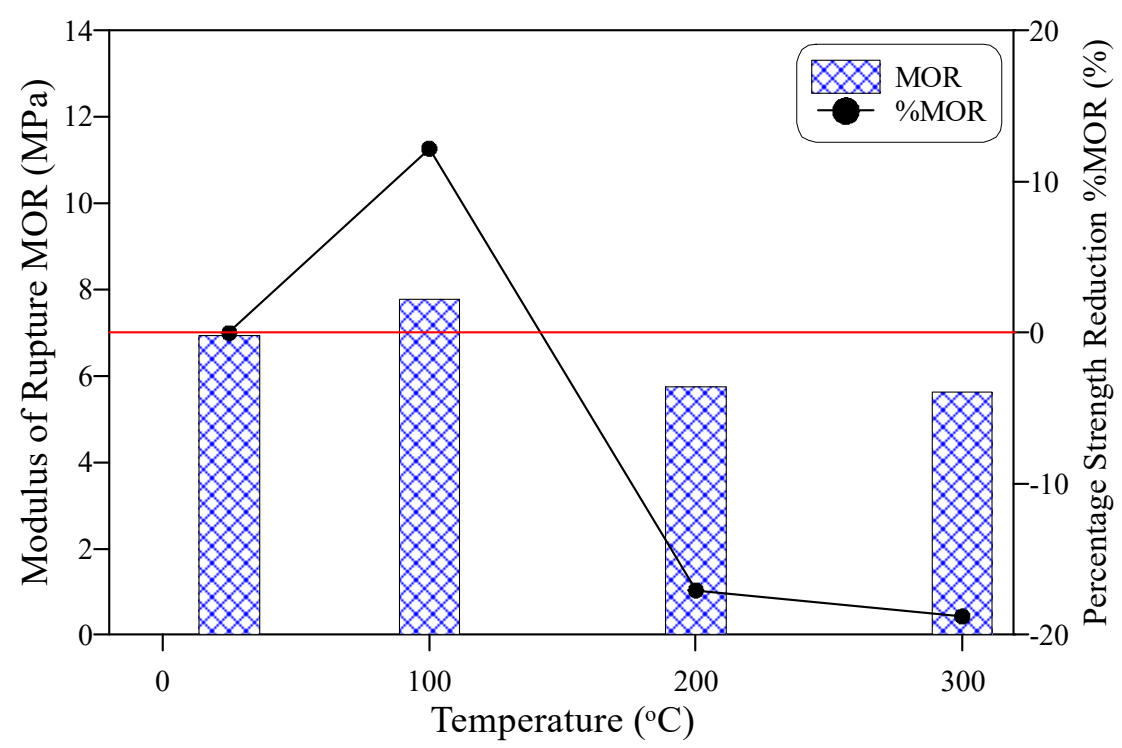

Figure 7. Modulus of rupture-temperature behavior.

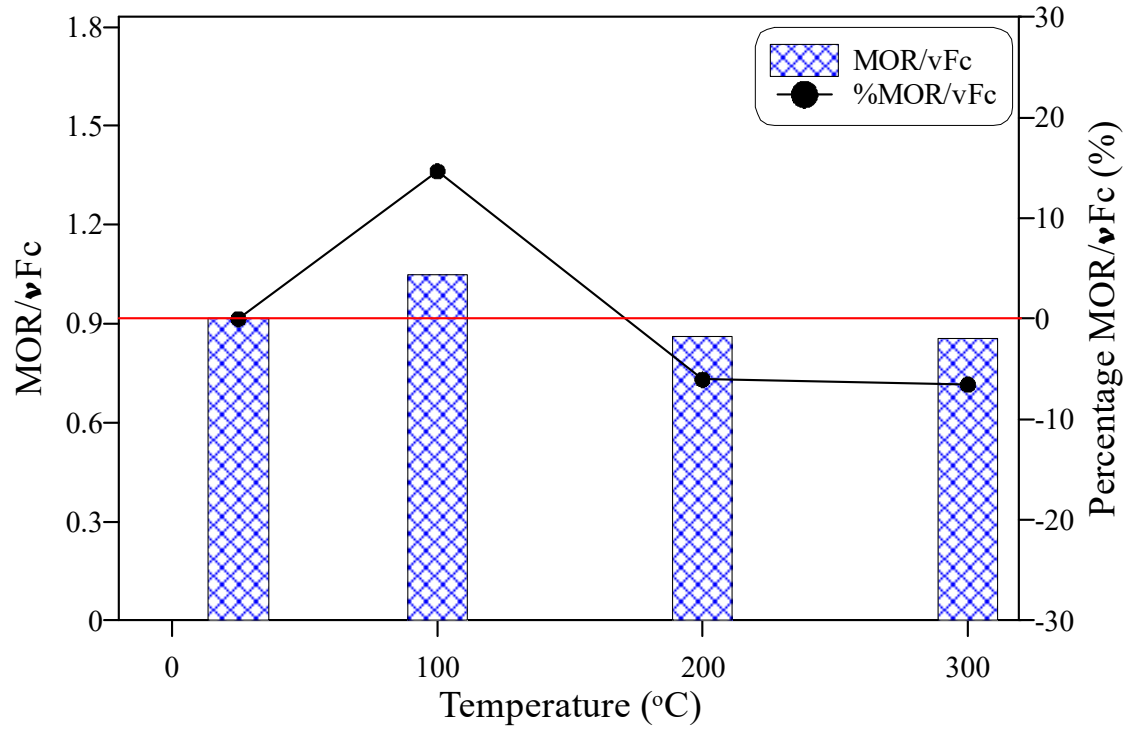

Figure 8. Behavior of normalized modulus of rupture with temperature increase.

\section{Repeated Impact Strength Results}

\subsection{Impact Number Results}

The impact strength in this study is represented by the retained numbers of impact blows at cracking and failure stages using the ACI 544-2R repeated impact test [18]. Figure 9a shows the recorded cracking number (N1) at each temperature and the percentage residual of $\mathrm{N} 1$ based on the record of the unheated specimens. It is obvious in the figure that ECC specimens retained higher $\mathrm{N} 1$ after exposure to $100{ }^{\circ} \mathrm{C}$ than that of the reference unheated specimens. On the other hand, a slight decrease in N1 was recorded after exposure to $200^{\circ} \mathrm{C}$, while a serious decrease occurred after exposure to $300{ }^{\circ} \mathrm{C}$. The retained $\mathrm{N} 1$ records after exposure to 100,200 , and $300^{\circ} \mathrm{C}$ were $51,41.5$, and 26 blows, respectively, while the unheated reference $\mathrm{N} 1$ was 43.3 . Hence, the cracking impact number increased by $17.7 \%$ after exposure to $100{ }^{\circ} \mathrm{C}$ and decreased by 4.2 and $40 \%$ after being heated to 200 and $300{ }^{\circ} \mathrm{C}$, respectively. 


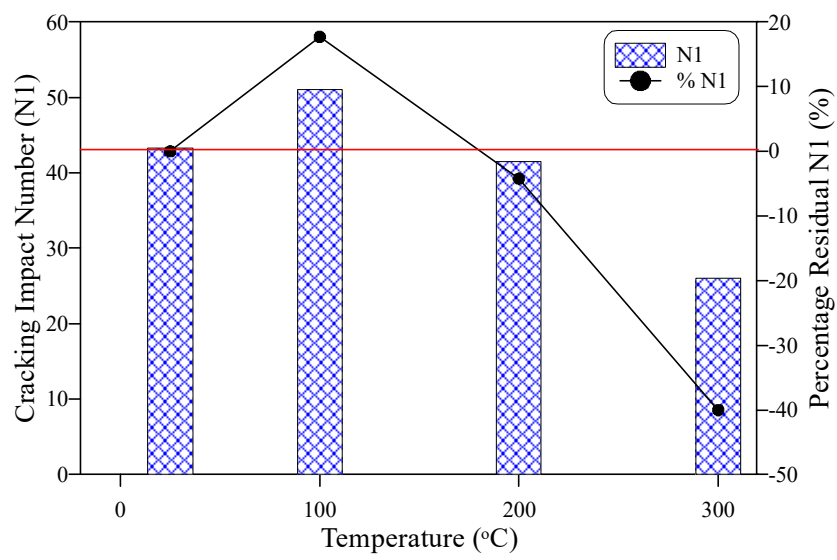

(a)

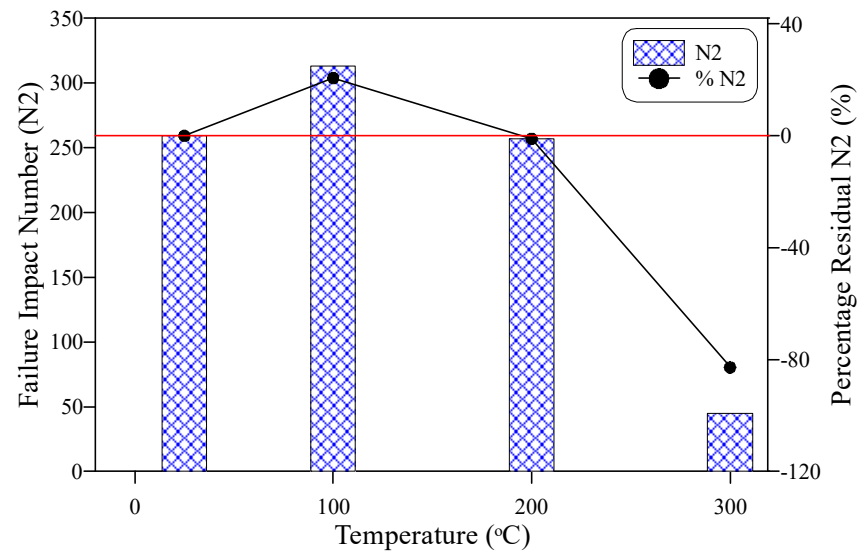

(b)

Figure 9. Impact number-temperature behavior (a) cracking number N1, (b) failure number N2.

Following a similar behavior with temperature increase, the failure impact number (N2) of specimens exposed to $100{ }^{\circ} \mathrm{C}$ was higher than the corresponding reference unheated $\mathrm{N} 2$, as shown in Figure 9b. This increase was also followed by a slight decrease after exposure to $200{ }^{\circ} \mathrm{C}$. However, the decrease of $\mathrm{N} 2$ after heating to $300{ }^{\circ} \mathrm{C}$ was much higher than its corresponding $\mathrm{N} 1$, which reflects the much higher effect of heating at this temperature on the failure impact resistance than the cracking impact resistance. The retained N2 values were $313,256.7$, and 44.7 after exposure to 100,200 , and $300{ }^{\circ} \mathrm{C}$, respectively, while the reference N2 was 259.3 blows. This means that N2 increased by approximately $21 \%$ after $100{ }^{\circ} \mathrm{C}$ exposure, while almost kept the same as the reference N2 with a slight decrease of $1 \%$ after exposure to $200{ }^{\circ} \mathrm{C}$. On the other hand, a serious $\mathrm{N} 2$ drop of approximately $83 \%$ was recorded for the specimens heated to $300{ }^{\circ} \mathrm{C}$.

The higher reduction after exposure to $300{ }^{\circ} \mathrm{C}$ is attributed to the microstructural changes that occurred at this temperature, where the complete melting of PP fibers left behind open micro-tubes that composed a network of connected continuous pores, which increased the porosity of the material and made it more brittle. Sahmaran et al. [62] indicated that the increase in PVA-ECC porosity was minimal $(0.2 \%)$ before fiber melting $\left(200{ }^{\circ} \mathrm{C}\right)$, while the complete melting of fibers increased the porosity to $5 \%$ and more after exposure to higher temperatures. Similarly, the increase in pore diameter was minimal after exposure to $200{ }^{\circ} \mathrm{C}$, while the exposure to $400{ }^{\circ} \mathrm{C}$ resulted in an increase in pore diameter by about $50 \%$, which explains the minor decrease in N1 and N2 after exposure to $200{ }^{\circ} \mathrm{C}$ and the significant decrease after exposure to $300{ }^{\circ} \mathrm{C}$. Bhat et al. [73] reported an increase in the tensile strength of PVA-ECC after exposure to $100^{\circ} \mathrm{C}$, which was attributed to the initial moisture loss due to the free pore water evaporation (form larger pores and capillary pores) 
and the hydration of the free fly ash that was not hydrated during the curing period. This was in turn attributed to the large amount of fly ash used in ECC. It should also be noticed that fibers were still working at $100{ }^{\circ} \mathrm{C}$, while the weakening of the bridging activity of fibers after exposure to $200^{\circ} \mathrm{C}$ (due to the partial melting) and the extra drying activity of temperature led to the slight reduction in $\mathrm{N} 1$ and $\mathrm{N} 2$ at this temperature level. It was also reported [73] that the moisture loss was less than $3 \%$ after $100{ }^{\circ} \mathrm{C}$ exposure, while it was more than $7 \%$ after exposure to $200{ }^{\circ} \mathrm{C}$.

To study the effect of compressive strength decrease with temperature on the response of impact numbers after temperature exposure, the impact numbers N1 and N2 were normalized by their corresponding compressive strength values at each temperature and presented in Figure 10a,b, respectively. It is obvious that the compressive strength was effective on the response on both N1 and N2, where the normalized responses exhibited differently from the corresponding responses of N1 and N2 (Figure 9a,b). Two differences can be distinguished between the responses of impact numbers and the normalized impact numbers. The first is that the normalized values of N1 at 100 and $200{ }^{\circ} \mathrm{C}$ were almost equal and thus as those of $\mathrm{N} 2$ and were both higher than the reference unheated normalized impact numbers, while the impact numbers (Figure 9) exhibited an increase at $100{ }^{\circ} \mathrm{C}$ and decreased at $200{ }^{\circ} \mathrm{C}$. The second difference is that the percentage reductions after exposure to $300^{\circ} \mathrm{C}$ of the normalized N1 and N2 (Figure 10) were less than those of N1 and N2 (Figure 9). The percentage residual normalized N1 values exhibited an approximate increase of 23 after exposure to 100 and $200{ }^{\circ} \mathrm{C}$ and an approximate decrease of $21 \%$ at $300{ }^{\circ} \mathrm{C}$, while the corresponding percentages of $\mathrm{N} 2$ were approximately 3,3 , and $-71 \%$ after exposure to 100,200 , and $300{ }^{\circ} \mathrm{C}$, respectively. These differences between the behaviors of impact records and their normalized values with temperature reflect the dependency of impact strength on the compressive strength when exposed to temperatures up to $300{ }^{\circ} \mathrm{C}$.

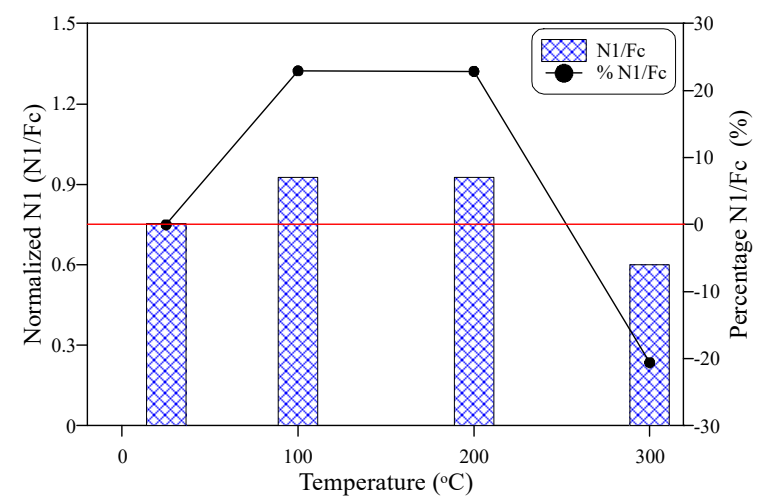

(a)

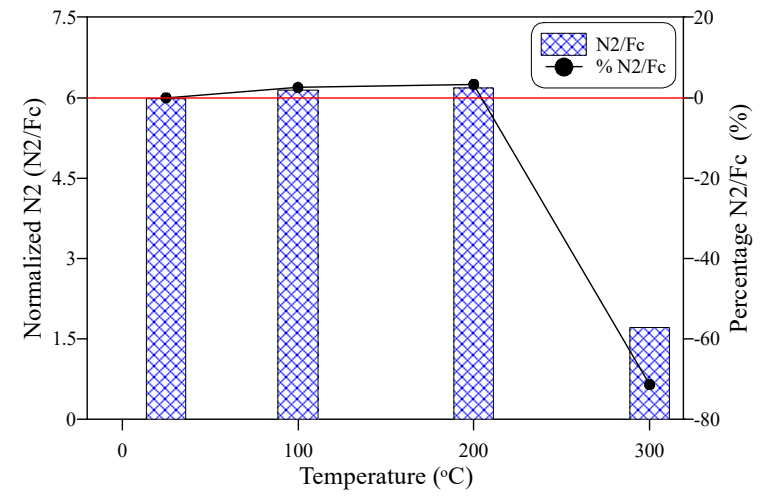

(b)

Figure 10. The behavior of normalized impact number with temperature increase (a) cracking number $\mathrm{N} 1$, (b) failure number N2. 


\subsection{Failure of Impact Specimens}

The behavior of repeated impact numbers with temperature is also confirmed by the failure patterns of the tested specimens. Figure 11 shows pictures of tested ECC disk specimens that were exposed to the investigated temperature levels. It is obvious in Figure 11a that the unheated reference specimens exhibited the usual ductile failure of fiberreinforced specimens, which is associated with a central fracture zone and multi-surface cracking. Owing to the test setup, the drop weight concentrically impacts the steel ball that is placed on the center of the top surface. With the increase of impact number, the top cementitious layer of this central zone (under the steel ball) starts cracking, which is followed by the fracturing of the below-surface layer. At this stage, the fibers try to work as a shield that composes what is termed as the shadow zone that protects the shaded cement matrix [74]. However, this shadow zone cannot stand long under the repeated impacts, especially since the used fiber was synthetic and not steel fibers. Therefore, the central surface impact zone completely fractures, as shown in Figure 11a, and the stress transfers to the outer perimeter of this zone leading to the surface cracking. At this stage, the bridging action of fibers becomes fully functional to slow down the crack propagation and widening. However, with the increasing of impact stresses, the fiber crack arresting capability is weakened and finally is broken, leading to further surface cracking and failure by the opening of one or more cracks [13].

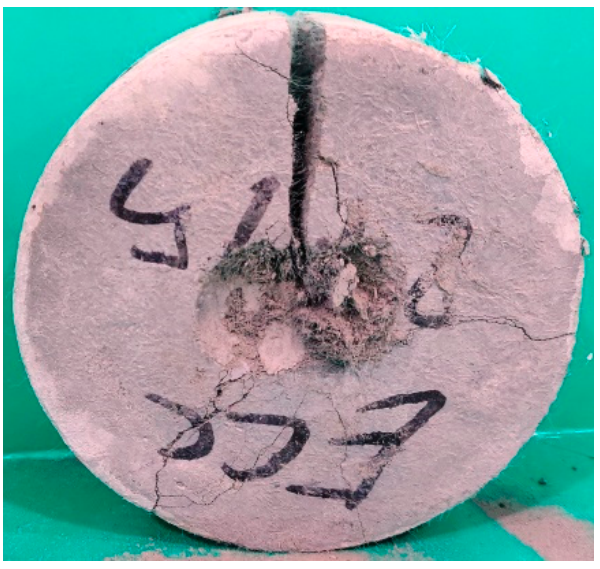

(a)

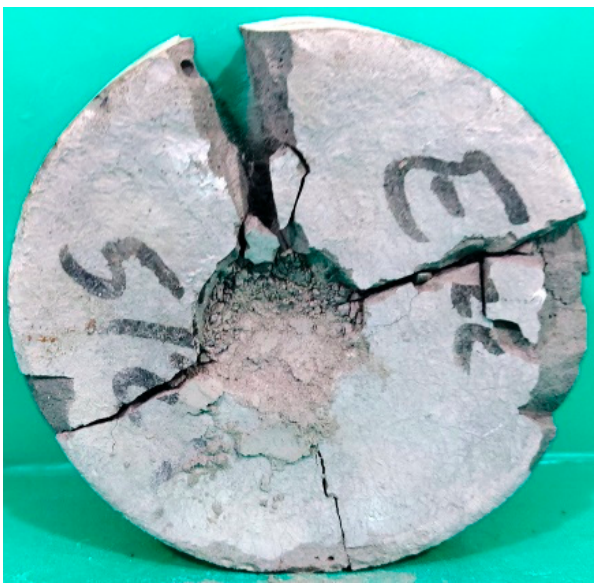

(c)

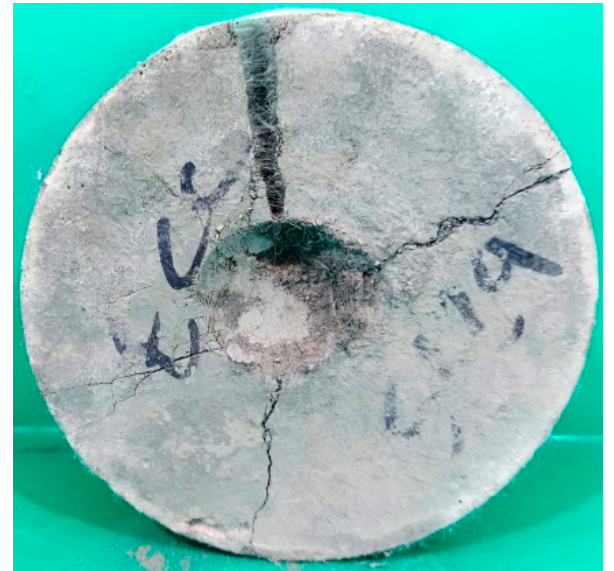

(b)

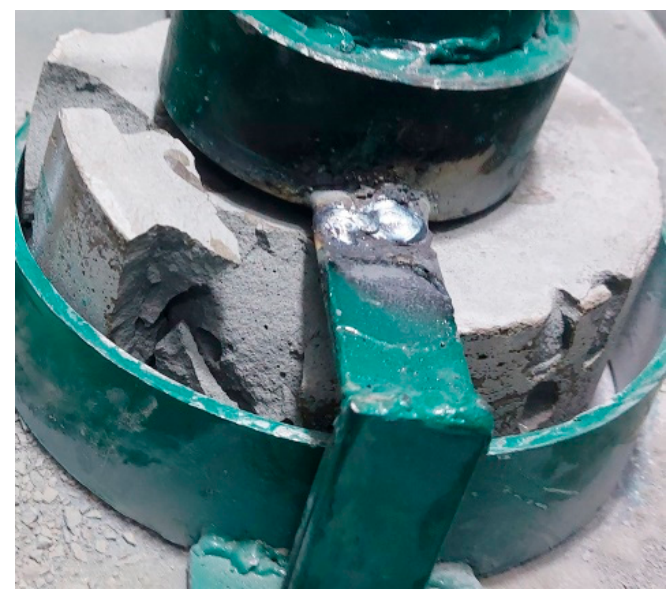

(d)

Figure 11. Tested disc specimens after failure (a) Reference R, (b) $100{ }^{\circ} \mathrm{C}$, (c) $200{ }^{\circ} \mathrm{C}$, (d) $300{ }^{\circ} \mathrm{C}$. 
The specimens exposed to $100{ }^{\circ} \mathrm{C}$ exhibited the same ductile cracking and failure behavior recorded for the reference specimens, where as shown in Figure 11b, the surface cracking and central fracturing are very similar to those that occurred on the surface of the unheated specimens (Figure 11a). Similarly, both figures show the presence of bridging PP fibers across the major opened cracks. This result supports the recorded N1 and N2 values that were not negatively affected by the exposure to $100^{\circ} \mathrm{C}$. On the other hand, the specimens exposed to $200^{\circ} \mathrm{C}$ exhibited central fracturing and multi-cracking, as shown in Figure 11c. However, PP fibers were observed neither in the central fracture zone nor across the widened cracks, which is attributed to the partial melting of PP fibers at this temperature. This failure type can be classified to be a transition state between ductile and brittle failure cases. Oppositely, the specimens exposed to $300{ }^{\circ} \mathrm{C}$ exhibited a rapid brittle failure after cracking that was not associated with a central fracturing zone, as shown in Figure 11d. This behavior is in complete agreement with the rapid deterioration of N2 that decreased by more than $80 \%$ of its reference number, where the specimens failed after less than 20 blows after the initial cracking.

\subsection{Impact Ductility}

One of the structural physical quantities that are used to define the response of flexural members under loads is ductility, which is a kind of quantitative measurement to define the capacity of the member to sustain plastic deformations [75]. A similar definition was also used in previous studies $[25,35,37]$ to estimate the plastic range of repeated impact that the specimen can withstand before failure. The impact ductility index (D) can thus be defined as the ratio of the failure impact number to the cracking impact number $(D=N 2 / N 1)$, which agrees with the original definition of flexural ductility, where it is defined as the ratio of the ultimate deflection to the deflection at the yielding of the tension steel bars [76].

As preceded in the previous sections, N1 and N2 records did not suffer serious deterioration after exposure to 100 and $200{ }^{\circ} \mathrm{C}$, where these values were slightly higher at $100{ }^{\circ} \mathrm{C}$ and slightly lower at $200{ }^{\circ} \mathrm{C}$ than those of the reference specimens. This behavior was reflected on the impact ductility, where as shown in Figure 12, the ductility index values were almost the same at the three temperatures, which were 6.0, 6.1, and 6.2 at room temperature, $100{ }^{\circ} \mathrm{C}$ and $200{ }^{\circ} \mathrm{C}$, respectively. These results reflect the ability of specimens heated to temperatures up to $200^{\circ} \mathrm{C}$ to withstand significant impact numbers after surface cracking. Oppositely, the ductility index of the specimens exposed to $300^{\circ} \mathrm{C}$ deteriorated significantly to only 1.7 , owing to the serious microstructural effects of temperature and melting of fibers that led to a sharp drop in N2.

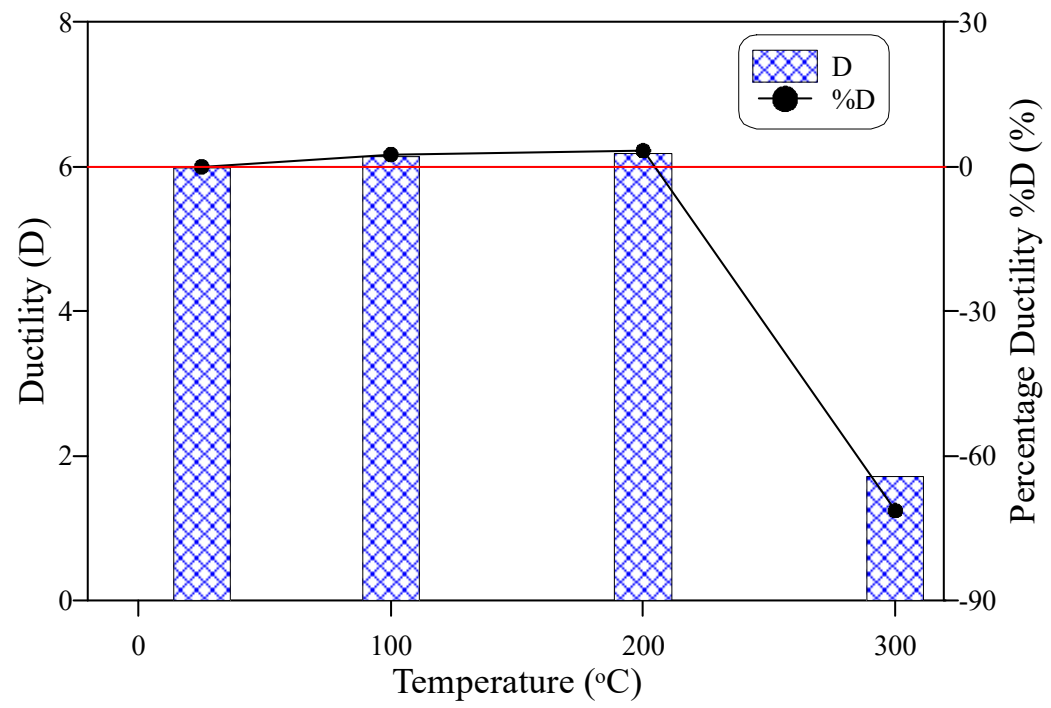

Figure 12. Impact ductility-temperature behavior. 
Figure 13 shows the ductility of the tested specimens using a different definition, which is the plastic impact number $(\mathrm{PN})$ that simply represents the difference between $\mathrm{N} 2$ and N1. Hence, it is the number of impacts absorbed by the specimen after cracking. This number is sometimes required to highlight the weakness of impact ductility to compare between different groups of specimens. Where in some cases, both N1 and N2 drop sharply to very low numbers, that is, although there are very few differences between N1 and N2, the ductility index was higher than expected. Figure 13 shows that $\mathrm{PN}$ of the specimens heated to $200{ }^{\circ} \mathrm{C}$ equals that of the unheated specimens, while that of the specimens heated to $100{ }^{\circ} \mathrm{C}$ is noticeably higher than both. Noting that the ductility was slightly higher at $200{ }^{\circ} \mathrm{C}$ than at $100{ }^{\circ} \mathrm{C}$ (Figure 12), PN reflects the higher plastic potential of specimens heated to $100{ }^{\circ} \mathrm{C}$ than those heated to $200{ }^{\circ} \mathrm{C}$. Another notice is that heating to $300{ }^{\circ} \mathrm{C}$ reduced the ductility index by approximately $71 \%$, while the percentage reduction in PN was approximately $91 \%$, which is noticeably higher. Thus, PN can be used as a secondary evaluation tool for ductility in the case of evaluating the residual repeated impact ductility.

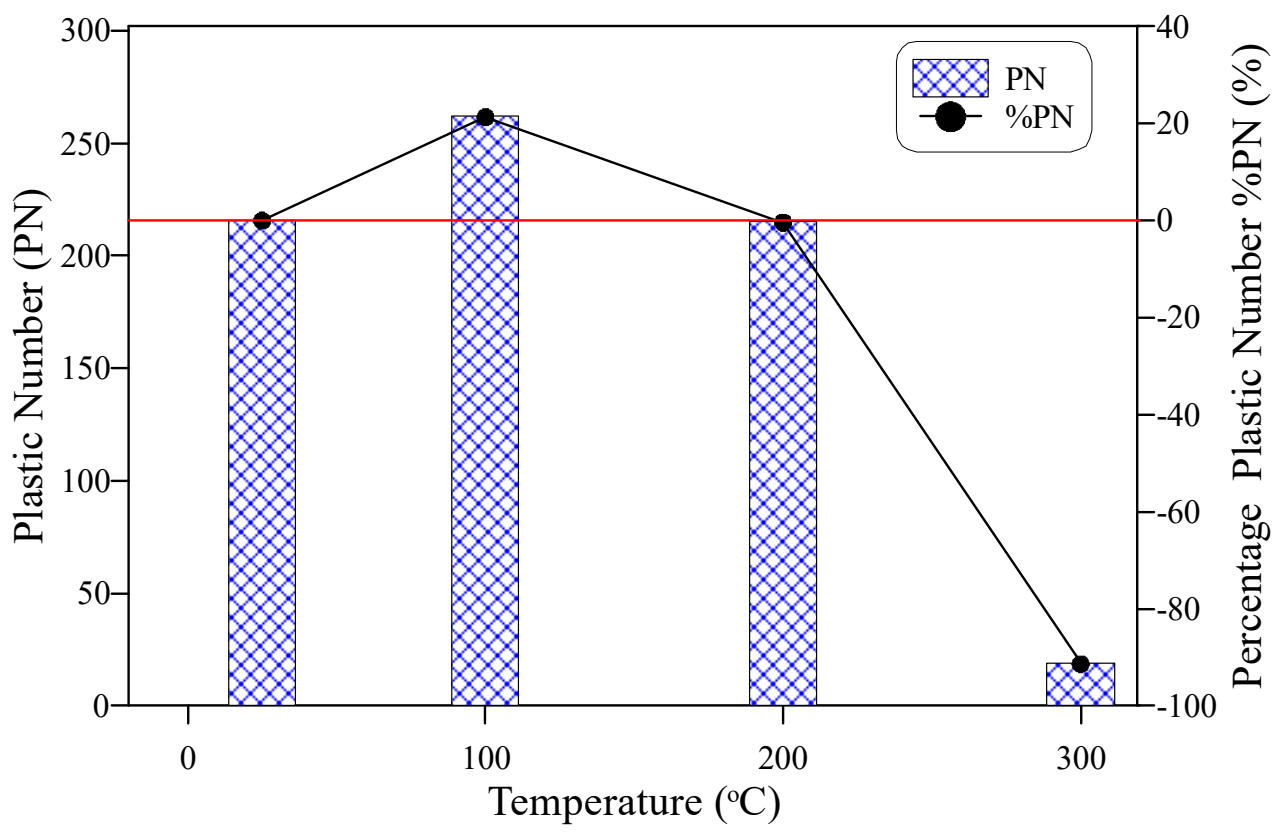

Figure 13. Plastic impact number-temperature behavior.

\section{Conclusions}

Engineered cementitious composite disk specimens were cast in this research to evaluate the repeated impact response using the ACI 544-2R procedure, while cube and prism specimens were used to evaluate the compressive strength and modulus of rupture. The specimens were heated to three temperatures of 100,200 , and $300{ }^{\circ} \mathrm{C}$, while a reference group of specimens was tested without heating. From the results obtained in this study, the followings are the concluded points,

1. Cracking (N1) and failure (N2) impact numbers increased after exposure to $100{ }^{\circ} \mathrm{C}$ compared to the unheated reference specimens, where $\mathrm{N} 1$ and $\mathrm{N} 2$ increased by approximately 18 and 21\%, respectively. The impact resistance in terms of N1 and $\mathrm{N} 2$ of ECC was almost unaffected by the exposure to $200{ }^{\circ} \mathrm{C}$, where the percentage decrease values of $\mathrm{N} 1$ and N2 were limited by approximately 4 and 1\%, respectively. However, exposure to $300{ }^{\circ} \mathrm{C}$ led to a significant impact resistance deterioration, which was more severe at failure than at the cracking stage with percentage decrease values of 40 and $83 \%$, respectively.

2. To evaluate the influence of compressive strength on the response of cracking numbers with temperature, N1 and N2 were normalized at each temperature level by the corresponding compressive strength records at these temperatures. The normalized 
N1 and N2 values reflected a noticeable dependency degree of the temperatureresponse of N1 and N2 on that of compressive strength. The normalized N1 and N2 were almost constant at 100 and $200{ }^{\circ} \mathrm{C}$, and both were higher than the unheated reference values, which is different behavior than that of $\mathrm{N} 1$ and $\mathrm{N} 2$ with temperature. The reductions at $300{ }^{\circ} \mathrm{C}$ were also lower for the normalized N1 and N1 cases than their corresponding N1 and N2 records. The different behaviors of normalized impact numbers from those of impact numbers reflect the noticeable degree of dependency of impact resistance on the compressive strength after exposure to temperatures of 100 to $300{ }^{\circ} \mathrm{C}$.

3. The specimens heated to $100{ }^{\circ} \mathrm{C}$ exhibited a ductile failure similar to that of the unheated specimens, which was characterized by the fracturing of the central zone of the top surface followed by surface multi-cracking and finally failed by the widening of one or more major cracks. Oppositely, the specimens exposed to $300{ }^{\circ} \mathrm{C}$ exhibited a sudden brittle failure without central fracturing or pre-failure multi-cracking. This behavior is attributed to the deterioration of the material microstructure and the complete melting of fibers. On the other hand, a kind of transition failure state between ductile and brittle failures was noticed for the specimens heated to $200{ }^{\circ} \mathrm{C}$, where a weaker central fracturing zone was observed associated with wider cracks.

4. The ductility index was comparable for the unheated specimens and those subjected to 100 and $200{ }^{\circ} \mathrm{C}$, which was approximately 6 with only a minor difference of about $3 \%$. This result is attributed to the behaviors of N1 and N2 with temperature, where the exposure to these temperature levels did not lead to any significant deterioration in the impact resistance. However, the sharp drop of the failure impact number after exposure to $300{ }^{\circ} \mathrm{C}$ reduced the impact ductility significantly to less than $30 \%$ of the unheated value.

Author Contributions: Conceptualization, S.R.A. and G.M.; methodology, S.H.A., S.R.A. and M.Ö.; validation, S.R.A., G.M., M.Ö. and N.I.V. resources, S.R.A., G.M. and R.A.A.-A.; software, S.H.A.; data curation, S.H.A. and R.A.A.-A.; visualization, N.I.V., R.A.A.-A. and M.Ö.; writing-original draft preparation, S.R.A., R.A.A.-A., and G.M.; writing-review and editing, S.R.A., M.Ö. and N.I.V.; supervision, S.R.A., M.Ö. and R.A.A.-A.; project administration, S.R.A. and S.H.A.; funding acquisition, R.A.A.-A. and N.I.V. All authors have read and agreed to the published version of the manuscript.

Funding: The research is partially funded by the Ministry of Science and Higher Education of the Russian Federation under the strategic academic leadership program 'Priority 2030' (Agreement 075-15-2021-1333 dated 30 September 2021).

Institutional Review Board Statement: Not applicable.

Informed Consent Statement: Not applicable.

Data Availability Statement: Not applicable.

Acknowledgments: The authors gratefully acknowledge the support of the material construction laboratory/Wasit University and Al-Sharq laboratory/Kut.

Conflicts of Interest: The authors declare no conflict of interest.

\section{References}

1. Li, V.C.; Leung, C.K.Y. Steady-state and multiple cracking of short random fiber composites. J. Eng. Mech. 1992, 118, 2246-2264. [CrossRef]

2. Li, V.C. From micromechanics to structural engineering: The design of cementitious composites for civil engineering applications. J. Struct. Mech. Earthq. Eng. 1993, 10, 37-48. [CrossRef]

3. Li, V.C.; Stang, H.; Krenchel, H. Micromechanics of crack bridging in fibre-reinforced concrete. Mater. Struct. 1993, 26, 486-494. [CrossRef]

4. Kanda, T.; Li, V.C. Multiple cracking sequence and saturation in fiber reinforced cementitious composites. Concr. Res. Technol. 1998, 9, 19-33. [CrossRef]

5. Li, V.C. Engineered Cementitious Composites (ECC)-Materials, Structural, and Durability Performance; University of Michigan: Ann Arbor, MI, USA, 2007. 
6. Sahmaran, M.; Lachemi, M.; Hossain, K.M.A.; Ranade, R.; Li, V.C. Influence of aggregate type and size on ductility and mechanical properties of engineered cementitious composites. ACI Mater. J. 2009, 106, 308.

7. Choi, W.-C.; Yun, H.-D.; Kang, J.-W.; Kim, S.-W. Development of recycled strain-hardening cement-based composite (SHCC) for sustainable infrastructures. Compos. Part B Eng. 2012, 43, 627-635. [CrossRef]

8. Said, S.H.; Razak, H.A.; Othman, I. Strength and deformation characteristics of engineered cementitious composite slabs with different polymer fibres. J. Reinf. Plast. Compos. 2015, 34, 1950-1962. [CrossRef]

9. Lu, C.; Li, V.C.; Leung, C.K.Y. Flaw characterization and correlation with cracking strength in Engineered Cementitious Composites (ECC). Cem. Concr. Res. 2018, 107, 64-74. [CrossRef]

10. Abid, S.R.; Hilo, A.; Daek, Y.H. Experimental tests on the underwater abrasion of engineered cementitious composites. Constr. Build. Mater. 2018, 171, 779-792. [CrossRef]

11. Ding, C.; Guo, L.; Chen, B.; Xu, Y.; Cao, Y.; Fei, C. Micromechanics theory guidelines and method exploration for surface treatment of PVA fibers used in high-ductility cementitious composites. Constr. Build. Mater. 2019, 196, 154-165. [CrossRef]

12. da Costa, F.B.P.; Righi, D.P.; Graeff, A.G.; da Silva Filho, L.C.P. Experimental study of some durability properties of ECC with a more environmentally sustainable rice husk ash and high tenacity polypropylene fibers. Constr. Build. Mater. 2019, 213, 505-513. [CrossRef]

13. Abid, S.R.; Abdul-Hussein, M.L.; Ali, S.H.; Kazem, A.F. Suggested modified testing techniques to the ACI 544-R repeated drop-weight impact test. Constr. Build. Mater. 2020, 244, 118321. [CrossRef]

14. Salaimanimagudam, M.P.; Suribabu, C.R.; Murali, G.; Abid, S.R. Impact response of hammerhead pier fibrous concrete beams designed with topology optimization. Period. Polytech. Civ. Eng. 2020, 64, 1244-1258. [CrossRef]

15. Ayoob, N.S.; Abid, S.R. Analysis of abrasion rates in concrete surfaces of hydraulic structures. IOP Conf. Ser. Mater. Sci. Eng. 2020, 888, 012052. [CrossRef]

16. Kim, G.-Y.; Choi, J.; Park, S.-E.; Kim, H.; Lee, Y.; Lee, B.Y. Response of UHPFRC and HDFRC under static and high-velocity projectile impact loads. Constr. Build. Mater. 2018, 188, 399-408. [CrossRef]

17. Feng, J.; Gao, X.; Li, J.; Dong, H.; He, Q.; Liang, J.; Sun, W. Penetration resistance of hybrid-fiber-reinforced high-strength concrete under projectile multi-impact. Constr. Build. Mater. 2019, 202, 341-352. [CrossRef]

18. ACI 544-2R. Measurement of Properties of Fiber Reinforced Concrete; American Concrete Institute: Farmington Hills, MI, USA, 1999.

19. Badr, A.; Ashour, A.F. Modified ACI drop-weight impact test for concrete. ACI Mater. J. 2005, 102, $249-255$.

20. Badr, A.; Ashour, A.F.; Platten, A.K. Statistical variations in impact resistance of polypropylene fibre-reinforced concrete. Int. J. Impact Eng. 2006, 32, 1907-1920. [CrossRef]

21. Rahmani, T.; Kiani, B.; Shekarchi, M.; Safari, A. Statistical and experimental analysis on the behavior of fiber reinforced concretes subjected to drop weight test. Constr. Build. Mater. 2012, 37, 360-369. [CrossRef]

22. Myers, J.J.; Tinsley, M. Impact resistance of blast mitigation material using modified ACI drop-weight impact test. ACI Mater. J. 2013, 110, 339-348.

23. Abid, S.R.; Abdul-Hussein, M.L.; Ayoob, N.S.; Ali, S.H.; Kadhum, A.L. Repeated drop-weight impact tests on self-compacting concrete reinforced with micro-steel fiber. Heliyon 2020, 6, e03198. [CrossRef]

24. Ismail, M.K.; Hassan, A.A. Impact resistance and mechanical properties of self-consolidating rubberized concrete reinforced with steel fibers. ASCE J. Mater. Civ. Eng. 2017, 29. [CrossRef]

25. Abid, S.R.; Murali, G.; Ali, S.H.; Kadhum, A.L.; Al-Gasham, T.S.; Fediuk, R.; Vatin, N.; Karelina, M. Impact performance of steel fiber-reinforced self-compacting concrete against repeated drop weight impact. Crystals 2021, 11, 91. [CrossRef]

26. Nili, M.; Afroughsabet, V. Combined effect of silica fume and steel fibers on the impact resistance and mechanical properties of concrete. Int. J. Impact Eng. 2010, 37, 879-886. [CrossRef]

27. Mastali, M.; Dalvand, A. The impact resistance and mechanical properties of self-compacting concrete reinforced with recycled CFRP pieces. Compos. B. Eng. 2016, 92, 360-376. [CrossRef]

28. Soroushian, P.; Nagi, M.; Alhozaimy, A. Statistical variations in the mechanical properties of carbon fiber reinforced concrete. $A C l$ Mater. J. 1992, 89, 131-138.

29. Wang, W.; Chouw, N. The behavior of coconut fibre reinforced concrete (CFRC) under impact loading. Constr. Build. Mater. 2017, 134, 452-461. [CrossRef]

30. Mahakavi, P.; Chithra, R. Impact resistance, microstructures and digital image processing on self-compacting concrete with hooked end and crimped steel fiber. Constr. Build. Mater. 2019, 220, 651-666. [CrossRef]

31. Song, P.S.; Wu, J.C.; Hwang, S.; Sheu, B.C. Statistical analysis of impact strength and strength reliability of steel-polypropylene hybrid fiber-reinforced concrete. Constr. Build. Mater. 2005, 19, 1-9. [CrossRef]

32. Jabir, H.A.; Abid, S.R.; Murali, G.; Ali, S.H.; Klyuev, S.; Fediuk, R.; Vatin, N.; Promakhov, V.; Vasilev, Y. Experimental tests and reliability analysis of the cracking impact resistance of UHPFRC. Fibers 2020, 8, 74. [CrossRef]

33. Abid, S.R.; Ali, S.H.; Goaiz, H.A.; Al-Gasham, T.S.; Kadhum, A.L. Impact resistance of steel fiber-reinforced self-compacting concrete. Mag. Civ. Eng. 2021, 105, 10504.

34. Murali, G.; Abid, S.R.; Amran, Y.M.; Abdelgader, H.S.; Fediuk, R.; Susrutha, A.; Poonguzhali, K. Impact performance of novel multi-layered prepacked aggregate fibrous composites under compression and bending. Structures 2020, 28, 1502-1515. [CrossRef] 
35. Murali, G.; Abid, S.R.; Karthikeyan, K.; Haridharan, M.K.; Amran, M.; Siva, A. Low-velocity impact response of novel prepacked expanded clay aggregate fibrous concrete produced with carbon nano tube, glass fiber mesh and steel fiber. Constr. Build. Mater. 2021, 284, 122749. [CrossRef]

36. Murali, G.; Abid, S.R.; Abdelgader, H.S.; Amran, M.Y.H.; Shekarchi, M.; Wilde, K. Repeated projectile impact tests on multi-layered fibrous cementitious composites. Inter. J. Civ. Eng. 2021, 19, 635-651. [CrossRef]

37. Murali, G.; Abid, S.R.; Amran, M.; Fediuk, R.; Vatin, N.; Karelina, M. Combined effect of multi-walled carbon nanotubes, steel fibre and glass fibre mesh on novel two-stage expanded clay aggregate concrete against impact loading. Crystals 2021, 11, 720. [CrossRef]

38. Haridharan, M.K.; Matheswaran, S.; Murali, G.; Abid, S.R.; Fediuk, R.; Amran, Y.M.; Abdelgader, H.S. Impact response of two-layered grouted aggregate fibrous concrete composite under falling mass impact. Constr. Build. Mater. 2020, $263,120628$. [CrossRef]

39. Ramakrishnan, K.; Depak, S.R.; Hariharan, K.R.; Abid, S.R.; Murali, G.; Cecchin, D.; Fediuk, R.; Amran, Y.M.; Abdelgader, H.S.; Khatib, J.M. Standard and modified falling mass impact tests on preplaced aggregate fibrous concrete and slurry infiltrated fibrous concrete. Constr. Build. Mater. 2021, 298, 123857. [CrossRef]

40. Ismail, M.K.; Hassan, A.A.A.; Lachemi, M. Performance of self-consolidating engineered cementious composite under dropweight impact loading. ASCE J. Mater. Civ. Eng. 2019, 31, 04018400. [CrossRef]

41. Brushlinsky, N.N.; Ahrens, M.; Sokolov, S.V.; Wagner, P. World Fire Statistics; Center of Fire Statistics of CTIF, International Association of Fire and Rescue Services: Ljubljana, Slovenia, 2018.

42. Arna'ot, F.H.; Abbass, A.A.; Abualtemen, A.A.; Abid, S.R.; Özakça, M. Residual strength of high strength concentric column-SFRC flat plate exposed to high temperatures. Constr. Build. Mater. 2017, 154, 204-218. [CrossRef]

43. Albrektsson, J.; Flansbjer, M.; Lindqvist, J.E.; Jansson, R. Assessment of Concrete Structures after Fire; SP Technical Rsearch Institute of Sweden: Borås, Sweden, 2011.

44. Arna'ot, F.H.; Abid, S.R.; Özakça, M.; Tayşi, N. Review of concrete flat plate-column assemblies under fire conditions. Fire Saf. J. 2017, 93, 39-52. [CrossRef]

45. Babalola, O.E.; Awoyera, P.O.; Le, D.-H.; Bendezú Romero, L.M. A review of residual strength properties of normal and high strength concrete exposed to elevated temperatures: Impact of materials modification on behaviour of concrete composite. Constr. Build. Mater. 2021, 296, 123448. [CrossRef]

46. Abrams, M.S. Compressive Strength of Concrete at Temperatures to $1600{ }^{\circ} \mathrm{F}$. Am. Concr. Inst. ACI 1971, $25,33-58$.

47. Phan, L.T.; Carino, N.J. Review of mechanical properties of HSC at elevated temperatures. J. Mater. Civ. Eng. 1998, 10, 58-64. [CrossRef]

48. Phan, L.T.; Carino, N.J. Code provisions for high strength concrete strength-temperature relationship at elevated temperatures. Mater. Struct. 2003, 36, 91-98. [CrossRef]

49. Cheng, F.P.; Kodur, V.K.R.; Wang, T.C. Stress-strain curves for high strength concrete at elevated temperatures. J. Mater. Civ. Eng. 2004, 16, 84-94. [CrossRef]

50. Al-Owaisy, S.R. Post heat exposure properties of steel fiber reinforced concrete. J. Eng. Sustain. Dev. 2006, 10, 194-207.

51. Netinger, I.; Kesegic, I.; Guljas, I. The effect of high temperatures on the mechanical properties of concrete made with different types of aggregates. Fire Saf. J. 2011, 46, 425-430. [CrossRef]

52. Guo, Y.; Zhang, J.; Chen, G.; Xie, Z. Compressive behaviour of concrete structures incorporating recycled concrete aggregates, rubber crumb and reinforced with steel fibre, subjected to elevated temperatures. J. Clean. Prod. 2014, 72, 193-203. [CrossRef]

53. Roufael, G.; Beaucour, A.-L.; Eslami, J.; Hoxha, D.; Noumowe, A. Influence of lightweight aggregates on the physical and mechanical residual properties of concrete subjected to high temperatures. Constr. Build. Mater. 2021, 268, 121221. [CrossRef]

54. Deng, Z.H.; Huang, H.Q.; Ye, B.; Wang, H.; Xiang, P. Investigation on recycled aggregate concretes exposed to high temperature by biaxial compressive tests. Constr. Build. Mater. 2020, 244, 118048. [CrossRef]

55. Sultan, H.K.; Alyaseri, I. Effects of elevated temperatures on mechanical properties of reactive powder concrete elements. Constr Build. Mater. 2020, 261, 120555. [CrossRef]

56. Husem, M. The effects of high temperature on compressive and flexural strengths of ordinary and high-performance concrete. Fire Saf. J. 2006, 41, 155-163. [CrossRef]

57. Al-Owaisy, S.R. Strength and elasticity of steel fiber reinforced concrete at high temperatures. J. Eng. Sustain. Dev. 2007, 11, 125-133.

58. Toric, N.; Boko, I.; Peroš, B. Reduction of postfire properties of high-strength concrete. Adv. Mater. Sci. Eng. 2013, 2013. [CrossRef]

59. Alimrani, N.; Balazs, G.L. Investigations of direct shear of one-year old SFRC after exposed to elevated temperatures. Constr. Build. Mater. 2020, 254, 119308. [CrossRef]

60. Mehdipour, S.; Nikbin, I.M.; Dezhampanah, S.; Mohebbi, R.; Moghadam, H.; Charkhtab, S.; Moradi, A. Mechanical properties, durability and environmental evaluation of rubberized concrete incorporating steel fiber and metakaolin at elevated temperatures. J. Clean Prod. 2020, 254, 120126. [CrossRef]

61. Al-Ameri, R.A.; Abid, S.R.; Murali, G.; Ali, S.H.; Özakça, M. Residual repeated impact strength of concrete exposed to elevated temperatures. Crystals 2021, 11, 941. [CrossRef]

62. Sahmaran, M.; Lachemi, M.; Li, V. Assessing mechanical properties and microstructure of fire-damaged engineered cementitious composites. ACI Mater. J. 2010, 107, 297-304. 
63. Şahmaran, M.; Özbay, E.; Yücel, H.E.; Lachemi, M.; Li, V.C. Effect of fly ash and PVA fiber on microstructural damage and residual properties of engineered cementitious composites exposed to high temperatures. J. Mater. Civ. Eng. 2011, 23, 1735-1745. [CrossRef]

64. Çavdar, A. A study on the effects of high temperature on mechanical properties of fiber reinforced cementitious composites. Compos. Part B Eng. 2012, 43, 2452-2463. [CrossRef]

65. Li, Q.; Gao, X.; Xu, S.; Peng, Y.; Fu, Y. Microstructure and mechanical properties of high-toughness fiber-reinforced cementitious composites after exposure to elevated temperatures. J. Mater. Civ. Eng. 2016, 28, 04016132. [CrossRef]

66. Liu, J.-C.; Tan, K.H.; Fan, S.-X. Residual mechanical properties and spalling resistance of strain-hardening cementitious composite with Class C fly ash. Constr. Build. Mater. 2017, 181, 253-265. [CrossRef]

67. Li, Q.-H.; Sun, C.-J.; Xu, S.-L. Thermal and mechanical properties of ultrahigh toughness cementitious composite with hybrid PVA and steel fibers at elevated temperatures. Compos. Part B Eng. 2019, 176, 107201. [CrossRef]

68. Yu, Z.; Yuan, Z.; Xia, C.; Zhang, C. High temperature flexural deformation properties of engineered cementitious composites (ECC) with hybrid fiber reinforcement. Res. Appl. Mater. Sci. 2020, 2, 17-26. [CrossRef]

69. Shang, X.; Lu, Z. Impact of high temperature on the compressive strength of ECC. Adv. Mater. Sci. Eng. 2014, 2014. [CrossRef]

70. Rafiei, P.; Shokravi, H.; Mohammadyan-Yasouj, S.E.; Koloor, S.S.R.; Petru, M. Temperature impact on engineered cementitious composite containing basalt fibers. Appl. Sci. 2021, 11, 6848. [CrossRef]

71. Wang, Z.-b.; Han, S.; Sun, P.; Liu, W.-k.; Wang, Q. Mechanical properties of polyvinyl alcohol-basalt hybrid fiber engineered cementitious composites with impact of elevated temperatures. J. Cent. South Univ. 2021, 28, 1459-1475. [CrossRef]

72. Aslani, F.; Wang, L. Fabrication and characterization of an engineered cementitious composite with enhanced fire resistance performance. J. Clean. Prod. 2019, 221, 202-214. [CrossRef]

73. Bhat, P.S.; Chang, V.; Li, M. Effect of elevated temperature on strain-hardening engineered cementitious composites. Constr. Build. Mater. 2014, 69, 370-380. [CrossRef]

74. Horszczaruk, E.K. Hydro-abrasive erosion of high performance fiber-reinforced concrete. Wear 2009, 267, 110-115. [CrossRef]

75. Abbass, A.A.; Abid, S.R.; Arnaot, F.H.; Al-Ameri, R.A.; Özakça, M. Flexural response of hollow high strength concrete beams considering different size reductions. Structures 2019, 23, 69-86. [CrossRef]

76. Abbass, A.A.; Arnaot, F.H.; Abid, S.R.; Özakça, M. Flexural behavior of ECC hollow beams incorporating different synthetic fibers. Front. Struct. Civ. Eng. 2021, 15, 399-411. [CrossRef] 